\title{
Water Resources of Jefferson Davis Parish, Louisiana
}

\section{Introduction}

Information concerning the availability, use, and quality of water in Jefferson Davis Parish, Louisiana (fig. 1), is critical for proper water-supply management. The purpose of this fact sheet is to present information that can be used by water managers, parish residents, and others for stewardship of this vital resource. Information on the availability, past and current use, use trends, and water quality from groundwater and surfacewater sources in the parish is presented. Previously published reports (see References Cited section) and data stored in the U.S. Geological Survey's National Water Information System (http://waterdata.usgs.gov/nwis) are the primary sources of the information presented here.

In 2010, about 175.06 million gallons per day (Mgal/d) of water were withdrawn in Jefferson Davis Parish, including about $140.46 \mathrm{Mgal} / \mathrm{d}$ from groundwater sources and 34.61 $\mathrm{Mgal} / \mathrm{d}$ from surface-water sources ${ }^{1}$ (table 1). Withdrawals for rice irrigation accounted for about 76 percent $(133.09 \mathrm{Mgal} / \mathrm{d})$ of the total water withdrawn (table 2). Other categories of use included public supply, industrial, rural domestic, livestock, general irrigation, and aquaculture. Water-withdrawal data collected at 5-year intervals from 1960 to 2010 (fig. 2) indicated that water withdrawals in Jefferson Davis Parish peaked in 1980. Withdrawals for rice irrigation have ranged from a low of $121.73 \mathrm{Mgal} / \mathrm{d}$ in 1960 to a high of $319 \mathrm{Mgal} / \mathrm{d}$ in 1980 (U.S. Geological Survey, 2014a).

${ }^{1}$ Water-withdrawal data is based on estimated or reported site-specific data and aggregated data, which is distributed to sources. For a full description of wateruse estimate methodology, see Data Collection in Sargent, 2011. Tabulation of withdrawals in the text and tables may produce different totals because of rounding; nonrounded numbers are used for calculation of total withdrawals.

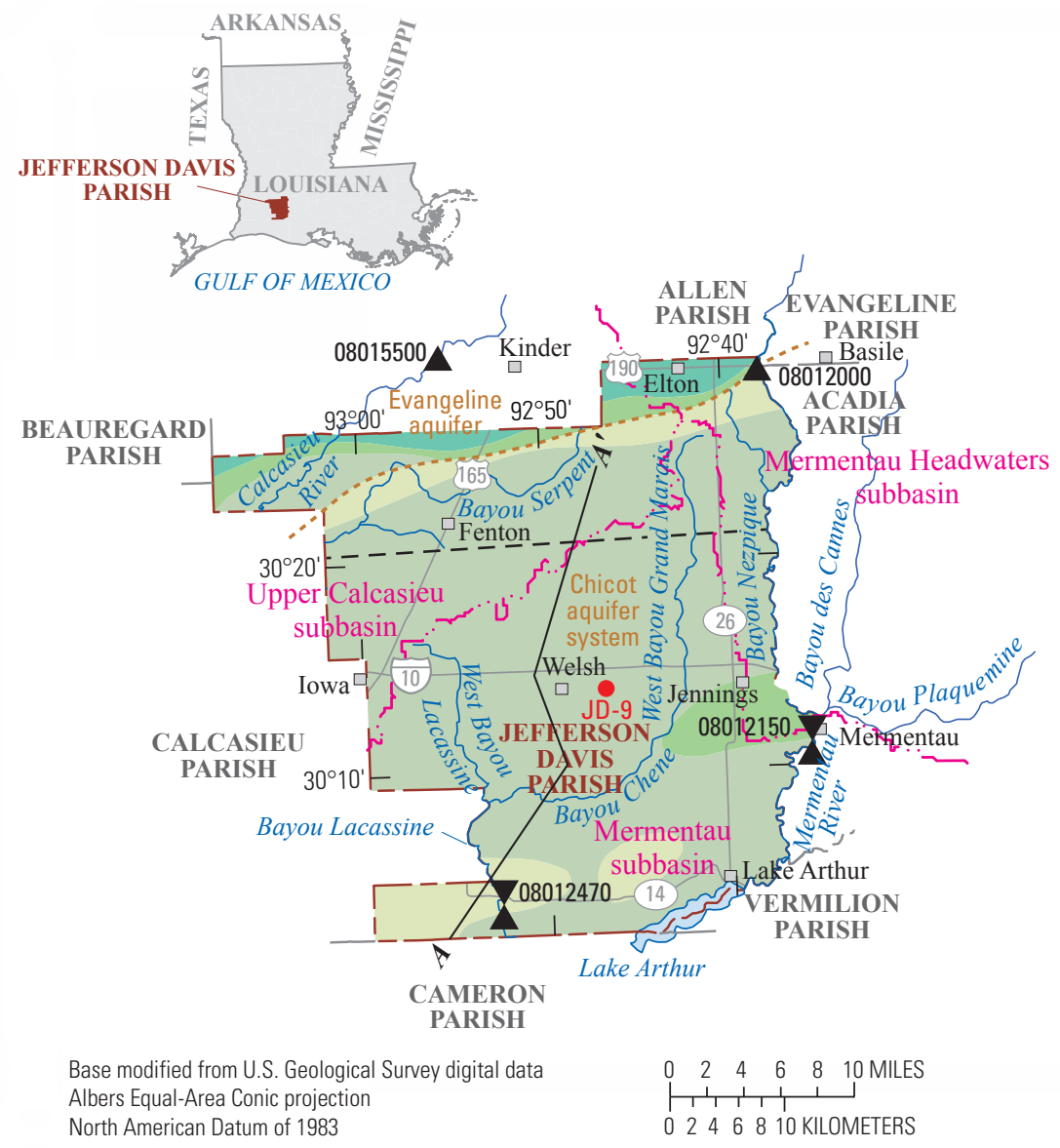

\section{EXPLANATION}

Approximate altitude of base of fresh groundwater, in feet below National Geodetic Vertical Datum of 1929 (NGVD 29) (modified from Smoot, 1988; Nyman, 1989)Deepest freshwater contained within Chicot aquifer system, except where noted 300 to 499

500 to 899

900 to 1,499

1,500 to 2,099

Approximate boundary of area showing deepest freshwater contained within underlying Evangeline aquifer

\section{$A-A^{\prime}$ Line of section (see fig. 3) \\ - - - Approximate boundary between the undifferentiated to the south \\ - - - River subbasin boundary \\ JD-9 Well for which hydrograph is shown (see fig. 4) \\ ${ }_{08015500} \quad$ U.S. Geological Survey surface-water discharge site and number} sand to the north and the upper and lower sands

$08012150 \quad$ U.S. Geological Survey surface-water quality site and number (see table 4)
Albers Equal-Area Conic projection
North American Datum of 1983 $\begin{array}{lllllll}0 & 2 & 4 & 6 & 8 & 10 \text { MILES } \\ \mid \begin{array}{ccccc}0 & 1 & 1 & 1 & 1\end{array} \\ 0 & 2 & 4 & 6 & 8 & 10 & \text { KILOMETERS }\end{array}$

Figure 1. Location of study area, Jefferson Davis Parish, Louisiana. 
Table 1. Water withdrawals, in million gallons per day, by source in Jefferson Davis Parish, Louisiana, 2010 (Sargent, 2011; B.P.

Sargent, unpub. data, 2011).

\begin{tabular}{lcc}
\hline \multicolumn{1}{c}{$\begin{array}{c}\text { Aquifer system or } \\
\text { surface-water body }\end{array}$} & Groundwater & Surface water \\
\hline Chicot aquifer system & 140.46 & \\
Bayou Chene & & 9.60 \\
Bayou Lacassine & 6.22 \\
Mermentau River & & 3.34 \\
West Bayou Grand Marais & & 0.02 \\
Other streams & 140.46 & 15.42 \\
Total & & 34.61 \\
\hline
\end{tabular}

Table 2. Water withdrawals, in million gallons per day, by use category in Jefferson Davis Parish, Louisiana, 2010 (modified from Sargent, 2011).

\begin{tabular}{lccr}
\hline \multicolumn{1}{c}{ Use category } & Groundwater & Surface water & Total \\
\hline Public supply & 4.83 & 0.00 & 4.83 \\
Industrial & 0.09 & 0.00 & 0.09 \\
Rural domestic & 0.39 & 0.00 & 0.39 \\
Livestock & 0.16 & 0.00 & 0.16 \\
Rice irrigation & 122.51 & 10.58 & 133.09 \\
General irrigation & 0.69 & 0.46 & 1.15 \\
Aquaculture & 11.78 & 23.57 & 35.35 \\
\cline { 2 - 4 } Total & 140.46 & 34.61 & 175.06 \\
\hline & & &
\end{tabular}

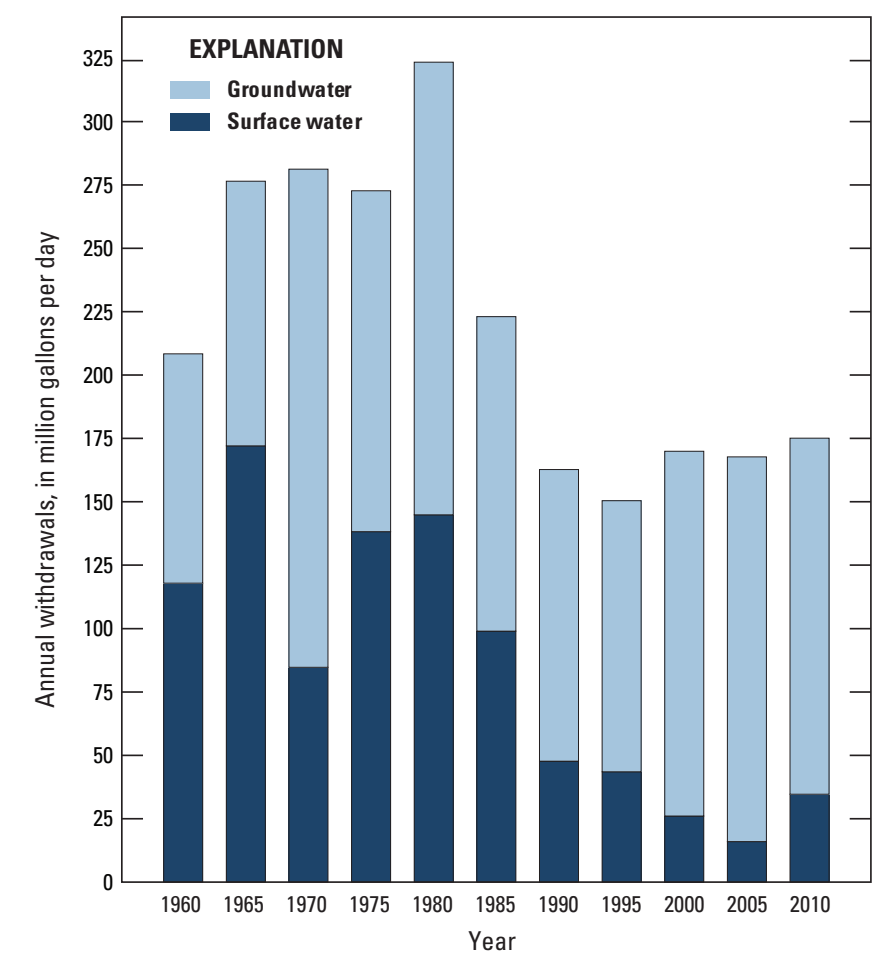

Figure 2. Water withdrawals in Jefferson Davis Parish, Louisiana, 1960-2010 (Sargent, 2011).

\section{Groundwater Resources}

The primary source of fresh groundwater (water with a chloride concentration of 250 milligrams per liter [mg/L] or less) in Jefferson Davis Parish is the Chicot aquifer system (fig. 3). The Chicot aquifer system contains freshwater to depths ranging from less than 400 feet (ft) below the National Geodetic Vertical Datum of 1929 (NGVD 29) near the northeastern corner of the parish to about $900 \mathrm{ft}$ below NGVD 29 near the town of Jennings (fig. 1). The underlying Evangeline aquifer contains freshwater to depths greater than 1,500 ft below NGVD 29 along the northern border of the parish but contains saltwater (water with a chloride concentration greater than $250 \mathrm{mg} / \mathrm{L}$ ) throughout the rest of the parish (Nyman, 1989). According to State well-registration records, there were no reported active water wells screened in the Evangeline aquifer in Jefferson Davis Parish in 2010.

\section{Chicot Aquifer System}

In 2003, the general direction of groundwater flow in the Chicot aquifer system in Jefferson Davis Parish was toward east-central parts of the parish (Lovelace and others, 2004). The direction of flow is a result of large groundwater withdrawals, primarily for rice irrigation in Jefferson Davis Parish and surrounding parishes, which are the major sources of discharge for the aquifer system. Recharge to the Chicot aquifer system is from infiltration of precipitation, vertical leakage, and lateral flow from other aquifers. Recharge from precipitation primarily occurs in areas north of Jefferson Davis Parish, where the aquifer system outcrops in parts of Allen, Beauregard, Evangeline, Rapides, and Vernon Parishes (Nyman, 1989).

In January 2003, water levels in the aquifer system ranged from about $25 \mathrm{ft}$ below NGVD 29 near the northwestern corner of the parish to about $50 \mathrm{ft}$ below NGVD 29 near Jennings. Water levels in the Chicot aquifer system in Jefferson Davis Parish generally have declined $50 \mathrm{ft}$ or more since groundwater development began around 1900 (Lovelace and others, 2004). Water levels in the aquifer fluctuate in response to seasonal pumping for irrigation. Water levels at well JD-9, located in central Jefferson Davis Parish (fig. 1), generally fluctuate 10-20 ft annually (fig. 4). Groundwater withdrawals in Jefferson Davis Parish in 2010 for various categories of use are presented in table 2. About 96 percent of groundwater withdrawals (135.14 Mgal/d) were used for agriculture, with the majority (122.51 Mgal/d) being used for rice irrigation.

The Chicot aquifer system consists of a complex series of alternating beds of unconsolidated gravel, sand, silt, and clay that thicken and dip to the south at a rate of about $30 \mathrm{ft}$ per mile (Nyman and others, 1990). In Jefferson Davis Parish, the system is characterized by massive beds of coarse sand and gravel separated by relatively thin beds of clay. In Jefferson Davis Parish, the Chicot aquifer system is composed of the shallow sand and the undifferentiated, upper, and lower sands (fig. 3). A surficial confining layer of clay, also called the Chicot aquifer system surficial confining unit, is present throughout the parish and ranges in thickness from $40 \mathrm{ft}$ in northern parts of the parish to as much as $240 \mathrm{ft}$ in the southwestern corner of the parish (Sargent, 2004).

The shallow sand of the Chicot aquifer system comprises scattered sand streaks and lenses within the surficial confining layer (Prakken, 2003). State well-registration records listed 20 active 


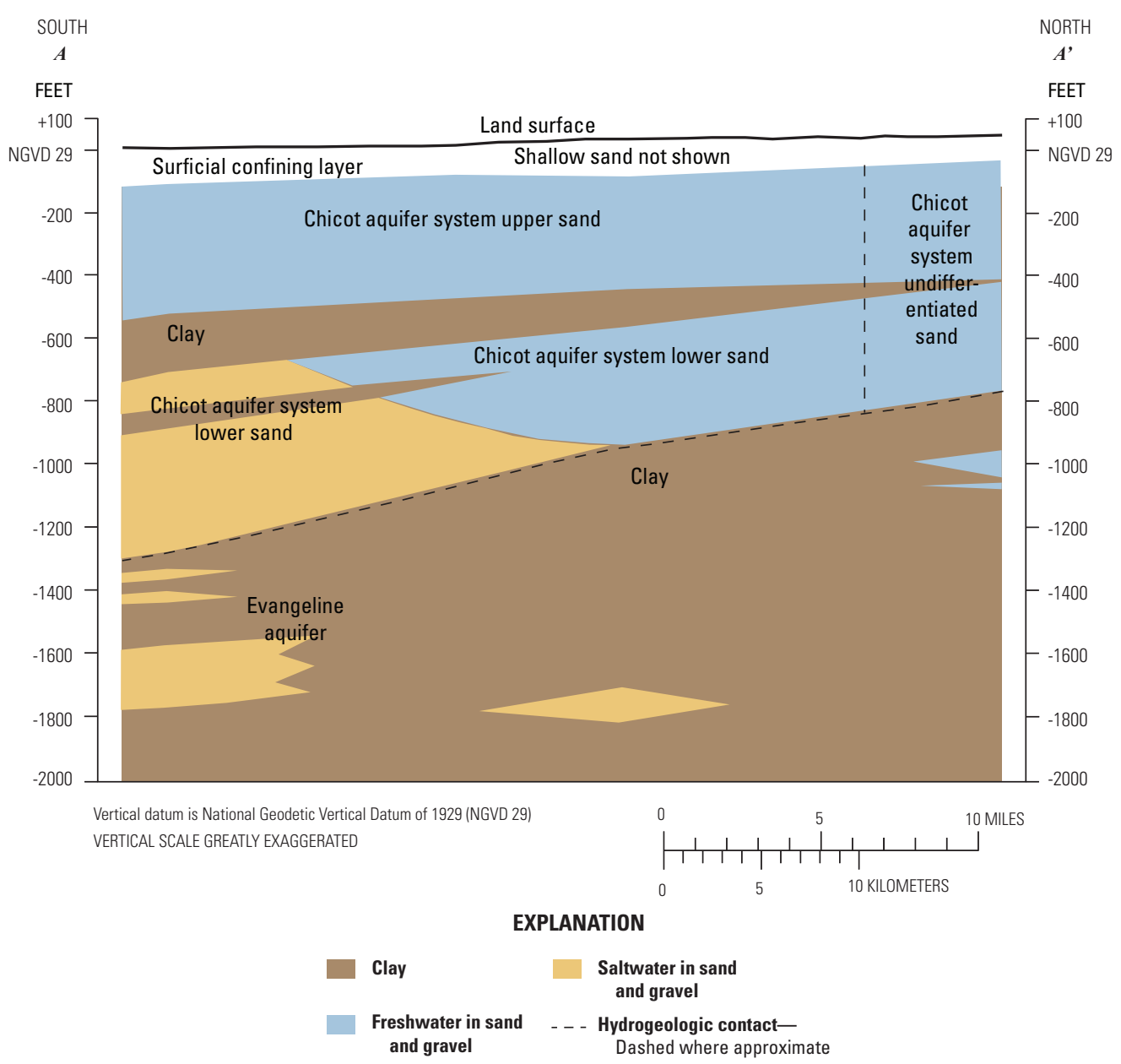

Figure 3. Generalized southto-north hydrogeologic section through Jefferson Davis Parish, Louisiana (modified from Stanley, Jr., and Maher, 1944). Trace of section shown on figure 1.

water wells screened in the shallow sand in Jefferson Davis Parish in 2010; all were domestic wells. Depths of these wells ranged from 13 to $105 \mathrm{ft}$ below land surface, with a median depth of 22 $\mathrm{ft}$ (Louisiana Department of Natural Resources, 2010). In 2010, there were no reported water withdrawals from the shallow sand in Jefferson Davis Parish.

Below the surficial confining layer and the shallow sand, the Chicot aquifer system consists of the undifferentiated, upper, and lower sands. The undifferentiated sand is a single massive sand present in the northern third of Jefferson Davis Parish. In the southern two-thirds of the parish, a clay layer generally is present, separating the aquifer system into the upper and lower sands. The altitude of the base of the Chicot aquifer system ranges from about $400 \mathrm{ft}$ below NGVD 29 in the northeastern corner of the parish to more than 1,000 ft below NGVD 29 at the southern boundary of the parish (Nyman, 1989). A transition zone from freshwater to saltwater is present in the lower sand at depths ranging from about 600 to $800 \mathrm{ft}$ below NGVD 29 in the central part of Jefferson Davis Parish (Nyman, 1989). Saltwater also is present at the base of the upper sand at depths ranging from about 170 to $360 \mathrm{ft}$ in western Jefferson Davis Parish and eastern Calcasieu Parish near the town of Iowa. Chloride concentrations in water from wells in the area have ranged from 100 to $550 \mathrm{mg} / \mathrm{L}$ (Nyman, 1989).

State well-registration records listed 1,761 active water wells screened in the undifferentiated, upper, and lower sands of the Chicot aquifer system in Jefferson Davis Parish in 2010, including 1,052 domestic, 608 irrigation, 69 public supply, and 32 industrial. Eighty-two percent of the wells were screened in the upper sand. Depths of these wells ranged from 60 to $760 \mathrm{ft}$ below land surface, with a median depth of $185 \mathrm{ft}$. Reported yields for the wells ranged from 4 to 6,000 gallons per minute (Louisiana Department of Natural Resources, 2010).

Freshwater in the undifferentiated, upper, and lower sands of the Chicot aquifer system is generally of similar quality (Nyman, 1989). A statistical summary of selected water-quality characteristics for freshwater samples collected from 223 wells screened in the undifferentiated, upper, and lower sands in Jefferson Davis Parish is presented in table 3. Freshwater from the Chicot aquifer system generally is moderately hard ${ }^{2}$ and falls within the U.S. Environmental Protection Agency's Secondary Maximum Contaminant Levels (SMCLs) ${ }^{3}$ for chloride, color, $\mathrm{pH}$, and dissolved solids. Samples generally exceed SMCLs for iron and manganese.

\section{Surface-Water Resources}

In 2010, about 34.61 Mgal/d of surface water were withdrawn in Jefferson Davis Parish for rice irrigation, general irrigation, and aquaculture (table 2). Current and potential surfacewater sources are found in the regional Calcasieu-Mermentau

${ }^{2}$ Hardness ranges, expressed as milligrams per liter of calcium carbonate, are as follows: 0-60, soft; 61-120, moderately hard; 121-180, hard; greater than 180, very hard (Hem, 1985).

${ }^{3}$ The SMCLs are nonenforceable Federal guidelines regarding cosmetic effects (such as tooth or skin discoloration) or aesthetic effects (such as taste, odor, or color) of drinking water. At high concentrations or values, health implications as well as aesthetic degradation might exist. SMCLs were established as guidelines for the States by the U.S. Environmental Protection Agency (1992). 


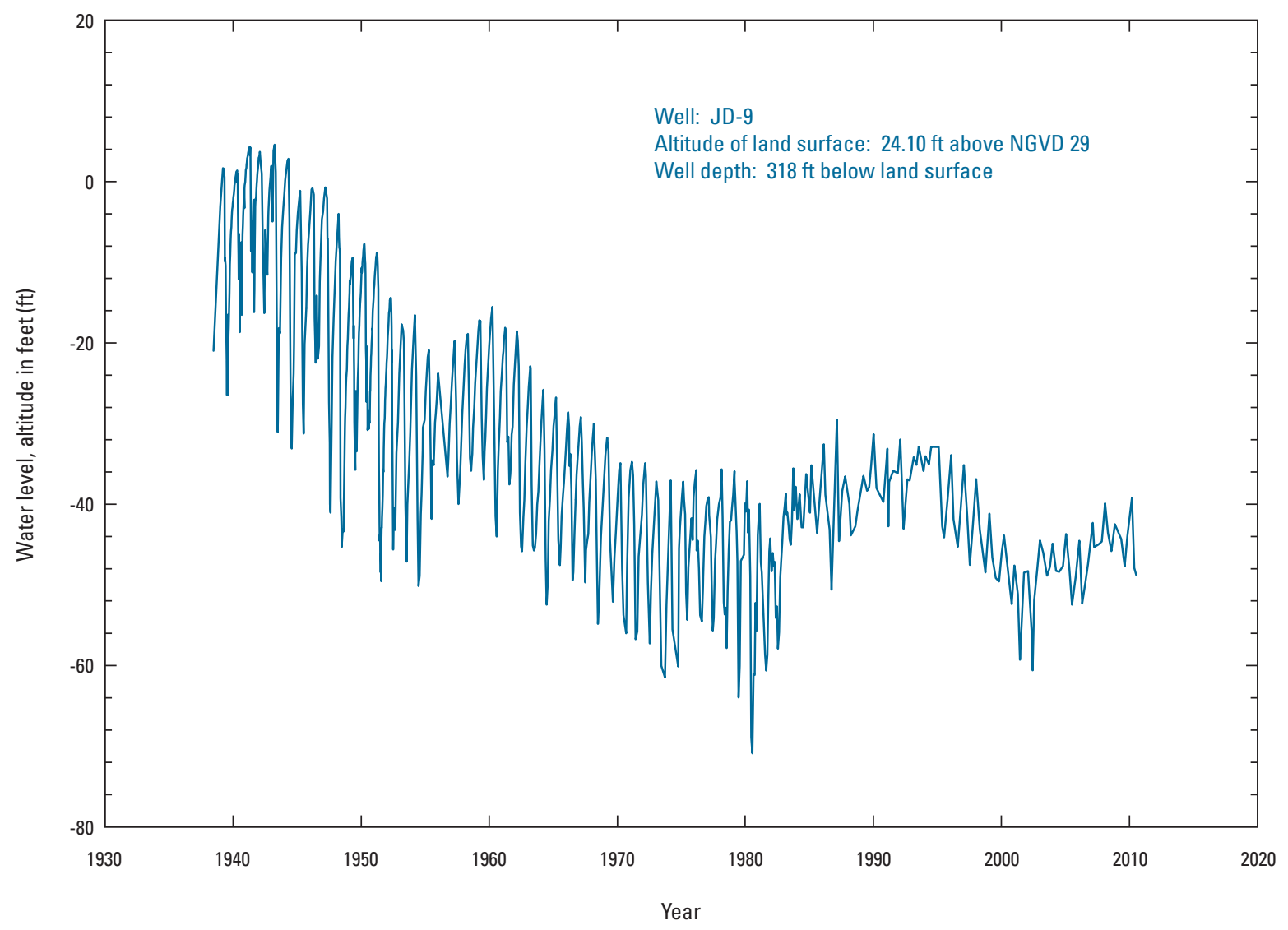

Figure 4. Water level in well JD-9, screened in the upper sand layer of the Chicot aquifer system in Jefferson Davis Parish, Louisiana (see fig. 1 for well locations; U.S. Geological Survey, 2011a). Land surface and water level are measured in feet (ft) relative to the National Geodetic Vertical Datum of 1929 (NGVD 29).

Table 3. Summary of selected water-quality characteristics for freshwater in the undifferentiated, upper, and lower sands of the Chicot aquifer system in Jefferson Davis Parish, Louisiana (U.S. Geological Survey, 2011b).

[Values are in milligrams per liter, except as noted. ${ }^{\circ} \mathrm{C}$, degrees Celsius; $\mathrm{PCU}$, platinum cobalt units; $\mu \mathrm{S} / \mathrm{cm}$, microsiemens per centimeter; $\mathrm{SU}$, standard units; $\mathrm{CaCO}_{3}$, calcium carbonate; $\mu \mathrm{g} / \mathrm{L}$, micrograms per liter; SMCL, Secondary Maximum Contaminant Level established by the U.S. Environmental Protection Agency (2011); NA, not applicable]

\begin{tabular}{|c|c|c|c|c|c|c|c|c|c|}
\hline & $\begin{array}{c}\text { Temper- } \\
\text { ature }\left({ }^{\circ} \mathrm{C}\right)\end{array}$ & $\begin{array}{l}\text { Color, } \\
\text { (PCU) }\end{array}$ & $\begin{array}{c}\text { Specific } \\
\text { conductance, } \\
\text { field } \\
(\mu \mathrm{S} / \mathrm{cm} \\
\left.\text { at } 25^{\circ} \mathrm{C}\right)\end{array}$ & $\begin{array}{l}\mathrm{pH}, \\
\text { field } \\
\text { (SU) }\end{array}$ & $\begin{array}{l}\text { Hardness } \\
\text { (as } \mathrm{CaCO}_{3} \text { ) }\end{array}$ & $\begin{array}{l}\text { Chloride, } \\
\text { filtered } \\
\text { (as CI) }\end{array}$ & $\begin{array}{c}\text { Iron, } \\
\text { filtered } \\
\text { ( } \mu \mathrm{g} / \mathrm{L} \text { as Fe) }\end{array}$ & $\begin{array}{c}\text { Manganese, } \\
\text { filtered } \\
\text { ( } \mu \mathrm{g} / \mathrm{L} \text { as } \mathrm{Mn})\end{array}$ & $\begin{array}{l}\text { Dissolved } \\
\text { solids, } \\
\text { filtered }\end{array}$ \\
\hline \multicolumn{10}{|c|}{ Chicot aquifer system, 1939-2009 (223 wells) } \\
\hline Median & 22 & 10 & 429 & 7.2 & 110 & 49 & 1,700 & 280 & 285 \\
\hline 90th percentile & 23 & 55 & 777 & 8.0 & 168 & 115 & 5,000 & 400 & 432 \\
\hline $\begin{array}{c}\text { Number of } \\
\text { samples }\end{array}$ & 84 & 16 & 159 & 50 & 111 & 216 & 34 & 33 & 38 \\
\hline $\begin{array}{l}\text { Percentage of } \\
\text { samples that } \\
\text { do not exceed } \\
\text { SMCLs }\end{array}$ & NA & 75 & NA & 88 & NA & 100 & 9 & 0 & 89 \\
\hline & NA & 15 & NA & $6.5-8.5$ & NA & 250 & 300 & 50 & 500 \\
\hline
\end{tabular}


drainage basin which is subdivided into three different drainage subbasins in Jefferson Davis Parish (fig. 1). The Mermentau Headwaters subbasin is found in the northeastern part of the parish and drains into the Mermentau subbasin, which is found in the central and southern parts of the parish and provides all withdrawals from identified source water bodies (19.18 Mgal/d). The Upper Calcasieu subbasin is found in the northwestern part of the parish and drains in a general southwesterly direction (U.S. Geological Survey, 2014b). In addition, $15.42 \mathrm{Mgal} / \mathrm{d}$ were withdrawn from unnamed streams (table 1).

Freshwater availability is a concern in the Mermentau subbasin, which drains southern Jefferson Davis Parish southward through Calcasieu, Cameron, and Vermilion Parishes, eventually reaching the Gulf of Mexico. Although the natural flow is toward the Gulf of Mexico, wind and tide can reverse flow in the southern part of Jefferson Davis Parish. Freshwater is maintained in surface-water bodies by several control structures in Calcasieu, Cameron, and Vermilion Parishes which limit the potential for encroachment of saltwater from the Gulf of Mexico (U.S. Army Corps of Engineers, 2013).

In northeastern Jefferson Davis Parish, the Mermentau Headwaters subbasin contains Bayou Nezpique, which forms the Mermentau River near the town of Mermentau with Bayou Plaquemine and Bayou des Cannes from neighboring Acadia Parish (fig. 1). During 1938-2013, the mean daily discharge of Bayou Nezpique near Basile (site number 08012000) was 797 cubic feet per second ( $\mathrm{ft}^{3} / \mathrm{s}$ ) (U.S. Geological Survey, 2013). In northwestern Jefferson Davis Parish, the Upper Calcasieu subbasin contains Bayou Serpent and the Calcasieu River (fig. 1). During 1922-2013, the mean daily discharge for the Calcasieu River near Kinder (site number 08015500; fig. 1) was 2,540 ft³ $/ \mathrm{s}$ (U.S. Geological Survey, 2013).

In the Mermentau subbasin, $0.02 \mathrm{Mgal} / \mathrm{d}$ were withdrawn from West Bayou Grand Marais, 3.34 Mgal/d were withdrawn from Mermentau River, $6.22 \mathrm{Mgal} / \mathrm{d}$ were withdrawn from Bayou Lacassine, and 9.60 Mgal/d were withdrawn from Bayou Chene (fig. 1; table 1). During the period 1987-2005, the average daily discharge of Bayou Lacassine near Lake Arthur (site number 08012470) was about $545 \mathrm{ft}^{3} / \mathrm{s}$ (U.S. Geological Survey, 2013). During the period 1989-2003, the average daily discharge of the Mermentau River at Mermentau (site number 08012150) was about 2,243 ft $3 / \mathrm{s}$ (U.S. Geological Survey, 2013). Wind and tide affect discharge at both sites, and reverse (negative) flow can occur at times during the year (U.S. Geological Survey, 2006, 2011c). Lake Arthur is a shallow lake formed by a widening of the Mermentau River that feeds and drains the lake (fig. 1). The lake stage varies several feet during the year, but the average altitude is estimated to be about $4 \mathrm{ft}$ above NGVD 29. At this altitude, the lake has a surface area of about 6 square miles and an estimated average depth of about $7 \mathrm{ft}$ (Shampine, 1971).

Water samples collected from Bayou Lacassine near Lake Arthur from 1989 to 2004 (table 4) indicated that, in general, the water is soft and does not exceed SMCLs for $\mathrm{pH}$ and concentrations of chloride, sulfate, and iron. Dissolved oxygen concentrations are generally less than $5 \mathrm{mg} / \mathrm{L}$, which is considered the minimum value for a diversified population of fresh, warmwater biota, including sport fish (Louisiana Department of Environmental Quality, 2008). Water samples collected from the Mermentau River at Mermentau during 1979-2011 indicated that the water is generally soft. The $\mathrm{pH}$ of the water and concentrations of chloride, sulfate, and iron are generally below the SMCLs (table 4). Dissolved oxygen concentration is generally less than $5 \mathrm{mg} / \mathrm{L}$. The water quality of Lake Arthur generally is similar to the water quality of the Mermentau River (Shampine, 1971).

\section{References Cited}

Louisiana Department of Environmental Quality, 2008, Environmental Regulatory Code, Title 33, Part IX, Subpart 1: Baton Rouge, Louisiana Department of Environmental Quality, accessed June 9, 2009, at http:www. deq.louisiana.gov/portal/tabid/1674/Default.aspx.

Louisiana Department of Natural Resources, 2010, Strategic Online Natural Resources Information System (SONRIS): Louisiana Department of Natural Resources database, accessed August 17, 2010, at http://sonris.com/.

Lovelace, J.K., Fontenot, J.W., and Frederick, C.P., 2004, Withdrawals, water levels, and specific conductance in the Chicot aquifer system in southwestern Louisiana, 2000-03: U.S. Geological Survey Scientific Investigations Report 2004-5212, 56 p., accessed December 6, 2012, at http://pubs.er.usgs.gov/ publication/sir20045212.

Nyman, D.J., 1989, Quality of water in freshwater aquifers in southwestern Louisiana: Louisiana Department of Transportation and Development Water Resources Technical Report no. 42, 22 p., 28 pls.

Nyman, D.J., Halford, K.J., and Martin, Angel, Jr., 1990, Geohydrology and simulation of flow in the Chicot aquifer system of southwestern Louisiana: Louisiana Department of Transportation and Development Water Resources Technical Report no. 50, $58 \mathrm{p}$.

Prakken, L.B., 2003, Quality of water used for domestic supply in the Chicot aquifer system of southwestern Louisiana, 1994-2001: Louisiana Department of Transportation and Development Water Resources Technical Report no. 71, 48 p.

Sargent, B.P., 2004, Thickness of the Chicot aquifer system surficial confining unit and location of shallow sands, southwestern Louisiana: Louisiana Department of Transportation and Development Water Resources Technical Report no. 73, 29 p.

Sargent, B.P., 2011, Water use in Louisiana, 2010: Louisiana Department of Transportation and Development Water Resources Special Report no. 17, $135 \mathrm{p}$.

Shampine, W.J., 1971, Chemical, biological, and physical data for the major lakes and reservoirs in Louisiana: Louisiana Department of Public Works Basic Records Report no. 5, 98 p.

Smoot, C.W., 1988, Louisiana hydrologic atlas map no. 3-Altitude of the base of freshwater in Louisiana: U.S. Geological Survey Water-Resources Investigations Report 86-4314, 1 sheet, accessed November 2, 2011, at http://pubs.er.usgs.gov/publication/wri864314.

Stanley, T.B., Jr., and Maher, J.C., 1944, Ground-water resources of Jefferson Davis and Acadia Parishes, Louisiana: Louisiana Department of Public Works, $93 \mathrm{p}$.

U.S. Army Corps of Engineers, 2013, Lock and waterway status 60 day forecast: U.S. Army Corps of Engineers, New Orleans District, accessed June 18, 2014, at http://www.mvn.usace.army.mil/portals/56/docs/ navigation/05_lockstatus28Mar13.pdf.

U.S. Environmental Protection Agency, 1992, Secondary drinking water regulations - Guidance for nuisance chemicals: U.S. Environmental Protection Agency publication EPA 810/K-92-001, 4 p., accessed July 29, 2009, at http://water.epa.gov/drink/contaminants/secondarystandards.cfm.

U.S. Environmental Protection Agency, 2011, 2011 Edition of the drinking water standards and health advisories: U.S. Environmental Protection Agency publication EPA 820-R-11-002, Office of Water, 12 p., accessed September 2, 2011, at http://water.epa.gov/action/advisories/drinking/upload/ dwstandards2011.pdf. 
Table 4. Summary of selected water-quality characteristics for Bayou Lacassine and Mermentau River in Jefferson Davis Parish, Louisiana (U.S. Geological Survey, 2011b).

[Values are in milligrams per liter, except as noted. $\mu \mathrm{S} / \mathrm{cm}$, microsiemens per centimeter; ${ }^{\circ} \mathrm{C}$, degrees Celsius; $\mathrm{SU}$, standard units; $\mathrm{CaCO}_{3}$, calcium carbonate; $\mu \mathrm{g} / \mathrm{L}$, micrograms per liter; <, less than; SMCL, Secondary Maximum Contaminant Level established by the U.S. Environmental Protection Agency (2011); NA, not applicable]

\begin{tabular}{|c|c|c|c|c|c|c|c|c|c|c|}
\hline & $\begin{array}{c}\text { Specific } \\
\text { conduc- } \\
\text { tance, } \\
\text { field ( } \mu \mathrm{S} / \\
\mathrm{cm} \\
\text { at } 25^{\circ} \mathrm{C} \text { ) }\end{array}$ & $\begin{array}{l}\text { Oxygen, } \\
\text { dis- } \\
\text { solved }\end{array}$ & $\begin{array}{l}\mathrm{pH}, \\
\text { field } \\
\text { (SU) }\end{array}$ & $\begin{array}{c}\text { Hard- } \\
\text { ness } \\
\text { (as } \\
\mathrm{CaCO}_{3} \text { ) }\end{array}$ & $\begin{array}{l}\text { Calcium, } \\
\text { filtered } \\
\text { (as Ca) }\end{array}$ & $\begin{array}{c}\text { Mag- } \\
\text { nesium, } \\
\text { filtered } \\
\text { (as Mg) }\end{array}$ & $\begin{array}{l}\text { Sodium, } \\
\text { filtered } \\
\text { (as Na) }\end{array}$ & $\begin{array}{l}\text { Chloride, } \\
\text { filtered } \\
\text { (as CI) }\end{array}$ & $\begin{array}{l}\text { Sulfate, } \\
\text { filtered } \\
\text { (as } \mathrm{SO}_{4} \text { ) }\end{array}$ & $\begin{array}{c}\text { Iron, } \\
\text { filtered } \\
\text { ( } \mu \mathrm{g} / \mathrm{L} \text { as } \\
\mathrm{Fe})\end{array}$ \\
\hline \multicolumn{11}{|c|}{ Bayou Lacassine near Lake Arthur, 1989-2004'1 } \\
\hline Median & 169 & 4.0 & 7.2 & 43 & 9.6 & 4.3 & 21 & 22 & 4.6 & 110 \\
\hline 10th percentile & 103 & 0.8 & 6.7 & 28 & 6.8 & 2.6 & 12 & 9.6 & 2.3 & $<30$ \\
\hline 90th percentile & 371 & 7.0 & 7.8 & 66 & 14 & 7.7 & 62 & 76 & 11 & 290 \\
\hline Number of samples & 72 & 62 & 72 & 46 & 46 & 47 & 47 & 69 & 69 & 47 \\
\hline $\begin{array}{l}\text { Percentage of samples } \\
\text { that do not exceed } \\
\text { SMCLs }\end{array}$ & NA & NA & 96 & NA & NA & NA & NA & 97 & 100 & 91 \\
\hline
\end{tabular}

that do not exceed

SMCLs

\begin{tabular}{|c|c|c|c|c|c|c|c|c|c|c|}
\hline \multicolumn{11}{|c|}{ Mermentau River at Mermentau, 1979-2011² } \\
\hline Median & 163 & 4.0 & 7.1 & 40 & 10 & 3.6 & 15 & 17 & 4.2 & 170 \\
\hline 10th percentile & 70 & 1.1 & 6.2 & 17 & 4.5 & 1.6 & 5.7 & 6.7 & 2.3 & 20 \\
\hline Number of samples & 192 & 176 & 192 & 126 & 126 & 126 & 124 & 188 & 187 & 103 \\
\hline $\begin{array}{l}\text { Percentage of samples } \\
\text { that do not exceed } \\
\text { SMCLs }\end{array}$ & NA & NA & 84 & NA & NA & NA & NA & 100 & 100 & 79 \\
\hline \multicolumn{11}{|c|}{ SMCLs } \\
\hline & NA & NA & $6.5-8.5$ & NA & NA & NA & NA & 250 & 250 & 300 \\
\hline
\end{tabular}

${ }^{1}$ Site number 08012470.

${ }^{2}$ Site number 08012150

U.S. Geological Survey, 2006, Annual water-data report 2005 [data for 08012470 Bayou Lacassine near Lake Arthur, LA]: USGS Water Resources of the United States, Publications-Annual Water Data Reports, p. 522, accessed July 29, 2011, at http://pubs.usgs.gov/wdr/2005/wdr-la-05-1/.

U.S. Geological Survey, 2011a, Groundwater levels for Louisiana: National Water Information System Web Interface, accessed July 28, 2011, at http://nwis.waterdata.usgs.gov/la/nwis/gwlevels.

U.S. Geological Survey, 2011b, Water-quality samples for Louisiana: National Water Information System Web Interface, accessed July 28, 2011, at http://nwis.waterdata.usgs.gov/la/nwis/qwdata.

U.S. Geological Survey, 2011c, Annual water-data report-Water-data report 2010 [data for 08012150 Mermentau River at Mermentau, LA]: U.S. Geological Survey Water Resources of the United States, accessed July 29, 2011, at http://wdr.water.usgs.gov/wy2010/pdfs/08012150.2010.pdf.

U.S. Geological Survey, 2013, USGS surface-water daily statistics for the Nation: National Water Information System Web Interface, accessed October 25, 2013, at http://waterdata.usgs.gov/nwis/dvstat?referred_ module $=$ sw.

U.S. Geological Survey, 2014a, U.S. Geological Survey Water Resources Cooperative Program-Louisiana Water Use Program, 1960-2010 data: Accessed September 3, 2014, at http://la.water.usgs.gov/WaterUse/default. asp.

U.S. Geological Survey, 2014b, Science in your watershed: Accessed June 18, 2014, at http://water.usgs.gov/wsc/acc/080802.html.
This fact sheet was published by the U.S. Geological Survey, in cooperation with the Louisiana Department of Transportation and Development (DOTD). Thanks are given to Zahir "Bo" Bolourchi, Director, Water Resources Programs, DOTD, who contributed to the content of the fact sheet.

\section{By Vincent E. White and Lawrence B. Prakken}

\section{For additional information, contact:}

Director, USGS Lower Mississippi-Gulf Water Science Center 3535 S. Sherwood Forest Blvd., Suite 120

Baton Rouge, LA 70816

E-mail: gs-w-lmg_center_director@usgs.gov

Fax: (225) 298-5490

Telephone: (225) 298-5481

Home Page: http://la.water.usgs.gov 